Marko Snoj

Inštitut za slovenski jezik Frana Ramovša ZRC SAZU, Ljubljana

\title{
Slovensko vedno, zmeraj in sorodno
}

Članek z etimološkega vidika obravnava slovenske prislove vẹ́dno, zmệraj, zmệrom, vmèr, namiru in namirom ter opozarja na možno zablodo, do katere lahko privede napačna interpretacija osamljenega indica.

The article presents an etymological analysis of the Slovene adverbs vẹdno, zmẹraj, zmẹrom, vmèr, namiru and namirom 'always' as well as indicates a possible pitfall caused by an incorrect interpretation of circumstantial evidence.

0 Namen etimološkega postopka je $\mathrm{z}$ upoštevanjem vseh nujnih delov, filološke evidence, primerjave in rekonstrukcije ter tistega najžlahtnejšega, ki sprašuje po semantični motivaciji izvora, ugotoviti resnico. Vprašanje, iz česa in kako so se tvorile besede, ki jih poznamo danes kot vẹ́dno, vẹnomer, zmẹraj, zmệrom in vmêr, je na tipološki ravni enak sodnemu vprašanju: »kaj se je zgodilo? $\mathrm{V}$ pravu se pri dokaznem postopku ob upoštevanju dejstev uporabljajo dokazi in manj povedni indici. $\mathrm{V}$ etimološkem primeru bi bili čisti in jasni dokazi glede izvora navedenih prislovov npr. izjave tistih, ki so besede tvorili, ali ustrezni izvleček iz dobro dokumentiranega govorjenega jezika tistega časa, v sodnem pa npr. zanesljivo pričevanje, video posnetek spornega dejanja ipd. Žal so tvorci navedenih besed že davno mrtvi, saj so po vsej verjetnosti živeli v srednjem veku, vsekakor pa pred 17. stoletjem, ko je bil jezik za današnje razmere še zelo slabo dokumentiran, tako da trdnih neposrednih dokazov omenjene vrste ne moremo pridobiti, zato bo treba resnico izluščiti iz dejstev in indicev.

1.0 Miklošič navaja po Volkmerju prislov vmêr v pomenu 'vedno, zmeraj'. Površen pogled na besedo nas privede na možno etimološko rešitev, po kateri naj bi bil to polovični prevod nemškega prislova immer, ki prav tako pomeni 'vedno, zmeraj': če je nemška beseda sestavljena iz predloga in ' $\mathrm{v}$ ' in nekega pomensko ne več jasnega elementa mer, potem smo Slovenci nemški in prevedli z $v$, drugi del domnevne nemške sestavljenke, kateremu nismo našli prevedka, pa obdržali in tako dobili svoj vmêr. Če to interpretacijo sprejmemo kot verodostojen in zadosten, čeprav osamljen indic, sodimo, da je prislov vmèr Nemec, ki se je naučil eno slovensko črko. Zdaj se nam ponudi priložnost obsoditi kar vse slovenske časovne prislove $\mathrm{z}$ elementom mer, torej vsaj še zmẹraj, zmẹrom in vệnomer: vsi imajo nemško jedro, levo in desno od njega pa je po nekaj slovenskih prislovnih okraskov.

1.1 Bog se usmili etimologa, ki bi ravnal tako tendenciozno, tako na mlin domnevni prikriti nemškosti slovenskega jezika! Kdor bi verjel zgornji razlagi, bi se namreč zavestno odrekel sodbi na osnovi celotne slike in verjel osamljenemu indicu, ki je v navedenem primeru zavajajoč. Če je očetu ime Dolfe, družina še ni nemškutarska, kakor tudi belokranjski Adlešiči niso nikdar bili nemško naselje, čeprav so 
poimenovani po priimku Adlešič, patronimiku od *Adleh, ki izvira iz stvnem. antroponima Adalleich. ${ }^{1}$

1.2 Kadar ni neposrednih dokazov, in tako je pri etimologiji v večini primerov, se resnica izlušči s tako interpretacijo vseh dejstev, indicev in okoliščin, ki ustvari celotno sliko davnega dogajanja, ta pa je skladna $\mathrm{z}$ doseženimi spoznanji vseh relevantnih poglavij jezikoslovja, od obvezujoče fonetike prek besedotvorja do semantike, in drugih, za etimologijo pomožnih znanosti, od zgodovine do psihologije. Če ta postopek izpeljemo korektno, znanstvena resnica o izvoru in etimologiji posamezne besede postane očitna, očitnost pa je enakovredna dokazu.

2.1 Sloven. vmër je bolj malo verjetno nastalo po zgledu nem. immer že zato, ker se je ta nem. prislov v srvnem. časih poleg immer glasil tudi iemmer in ker izvira iz stvnem. iommēr, to pa je sklop iz io <eo, kar že samo po sebi pomeni ‘vedno'. Ta beseda je otrdeli tožilnik samostalnika, ki je izpričan v got. aiws ‘čas, večnost'.2 Drugi del sklopa je primernik stvnem. mēr $(o)>$ srvnem. mēr $(e)>$ nem. $m e h r$ 'več'. ${ }^{3}$ Beseda $\mathrm{v}$ današnji nemščini ni paretimološko občutena kot sklop $\mathrm{z}$ in ' $\mathrm{v}$ ', v starejšem času pa tako občutenje zaradi vzglasnega ie- oz. io- sploh ni bilo mogoče. Tako je izredno malo verjetno, da bi si nem. prislov tako razlagal neki Slovenec, ki bi skladno s svojim razumevanjem potem tvoril sloven. vmër.

2.2 Poskus ponemčenja sloven. prislova vmër se dokončno izkaže za absurd, ko zberemo celotno besedno družino, ki obsega še istopomenske prislove venomẹr, zmệraj, zmệrom, zmệr, vúzmer, $\mathrm{k}$ temu pritegnemo še vẹdno, vẹ́no $\mathrm{z}$ elativoma prevẹ́dno in prevẹno, ter poskušamo ugotoviti njen resnični izvor s pomočjo celotne slike. Ključ za rešitev je Miklošičevo pojmovanje prislova venomệr kot izvornega sklopa *vb edbnó mêrrb, pri čemer *mếrb, ki se ohranja v nar. sloven. mẹr, rod. merî, pomeni 'smer'. Prislov je torej pomensko zelo podobno motiviran kot nem. zveza in einem fort 'neprestano', v kateri je fort prislov s pomenom 'naprej', pa tudi sloven. kar naprej, kar prav tako pomeni 'neprenehoma, stalno, vedno'. Tipološka vzporednica izkazuje veliko verjetnost, da se je pomen 'vedno' razvil iz 'neprestano', ta pa iz 'v eno (in isto) smer'. Domnevana šestzložna besedna zveza se je po odpadu šibkih polglasnikov razvila $\mathrm{v}$ trizložno, ki pa je bila za vsakdanjo rabo očitno še vedno predolga in se je zato eliptično skrajšala. Če je elipsa prizadela prilastek, se je zveza obrusila v vmër ${ }^{5}$ če jedro, pa v *vednọ. ${ }^{6}$

2.3 Domneva o prvotni predložni zvezi in elipsi postane še verjetnejša s primerom sloven. zmẹr 'vedno', ki ga navajata Cigale in Janežič, in ki ima vzporednico v hrv. kajk. vúzmer. ${ }^{7}$ To kaže na predložno zvezo *vъz (edbnó) mếrb s predlogom *vъz 'gor, ob, pri', ki je pomensko blizu predlogu $* v_{b}$.

\footnotetext{
${ }^{1}$ Stvnem. antroponim navaja Förstemann, Altdeutsches Namenbuch I, 174.

${ }^{2}$ Isti sklon se ohranja v stvnem. io, eo $>$ srvnem. ie $>$ nem. je 'kadar koli, nekoč', sekundarno distributivno 'po'.

${ }^{3}$ Pfeifer, Etymologisches Wörterbuch des Deutschen², 596, 574.

${ }^{4}$ Miklošič, Etymologisches Wörterbuch der slavischen Sprachen, 102, brez oznake akcenta.

${ }^{5}$ Prim. sloven. in širše sreča, kar je skrajšano iz dobra sreča.

${ }^{6}$ Prim. sloven. $v$ kratkem 'kmalu', kar je skrajšano iz v kratkem času. Tako, čeprav manj precizno razlago prislova vẹ́dno sem podal že v Slovenskem etimološkem slovarju, 708.

${ }^{7}$ Navaja Pleteršnik po Miklošiču iz Valjavčevih Narodnih pripovedk iz Varaždina in okolice.
} 
3.1 V odstavku 2.2 domnevano *vednọ < *vъ edbnọ (mêrrb) ne more biti izhodišče za današnji prislov vẹ́dno, ki ga pisci od Janeza Svetokriškega dalje zapisujejo kot ved$n u, \mathrm{tj} . \mathrm{z}$ refleksom izglasnega etimološkega $-o$ in ne $-Q$. Poleg tega tudi današnjega akcentskega stanja ni mogoče izpeljati iz domnevane, zgoraj navedene predložne zveze. Pri protestantih je znan le prislov veden, npr. ta Hudizh veden inu poufod okuli fuiemi fobmi grife. ${ }^{8}$ Ta prislov je mogoče razložiti iz $*_{v b}$ edbnל̌, kar je utegnilo po elipsi

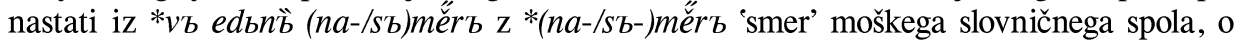
katerem glej spodaj 4.1. Pleteršnik navaja pridevnik vẹden, -dna 'stalen, neprenehen', za katerega domneva, da je tvorjen iz prislova. Rešitev, ki zapolni vrzeli v besedotvorni verigi, je domneva, da je iz zveze $<*_{v b}$ edbnל̌ (/na-/sb-/měr $r$ ) osamosvojeni prislov vedên deriviral pridevnik véden, katerega prislov je Janeza Svetokriškega vednu in današnji védno. Derivacija pridevnika iz prislova $\mathrm{z}$ akcentskim sredstvom ima zgled $\mathrm{v}$ tematskih pridevnikih tipa lẹp, sûh, za srednji spol lẹpo, súho ob prislovih lepộ, suhộ. Ta, nekoliko zapletena možnost se zdi vendarle verjetnejša od neposredne primerjave našega prislova $\mathrm{z}$ mak. vedno in blg. vednó 'skupaj' $<*^{*}$ ‘ edbnö, saj pomena 'vedno' ni mogoče izpeljati iz pomena 'skupaj', poleg tega bi v primeru takega izhodišča $\mathrm{v}$ slovenščini danes pričakovali **vé(d)no in ne vé(d)no.

3.2 Pomen 'neprenehoma' vključuje ponavljanje, kar se $\mathrm{v}$ jeziku rado izraža $\mathrm{z}$ reduplikacijo. Sloven. vên in vên 'neprenehoma' je tako mogoče razložiti iz *vẹno in vẹno, kar poleg veznika vsebuje še dvakrat izraženo različico véno, nastalo po asimilaciji $d n>n$. Izglasni $-o>-u$ je, če ne prej, odpadel po moderni vokalni redukciji, predhodnik akutiranega é pa je ali ostal kratek ali se v enozložnici skrajšal kot $\mathrm{v}$ prislovu bòlj < *bòl'e. Možnost, da bi bila sloven. zveza ven in ven prevedena iz nemške aus und aus, ne obstaja, saj zadnje po Grimmu' ${ }^{9}$ pomeni le $\mathrm{v}$ celoti, od začetka do konca'.

4.1 Navedena interpretacija prislova veden vključuje predpostavko, da je poleg *mêrr ženskega spola obstajal tudi tematski samostalnik *mêrr moškega spola. Njegov obstoj izkazujeta še prislova zmệraj in zmệrom s paralelama v hrv. čak. (Vodice) smìron, ${ }^{10}$ kajk. (Prigorje) zmêrim, (Bednja) zmêirem, ${ }^{11}$ na jugovzhodu Štajerske potrjena prislova namiru in namiri 'takoj, vedno' ter pri Cafu zapisani namirom 'vedno', zadnji trije $\mathrm{z} i$ iz $e$ pred $r{ }^{12}$ Prve štiri prislove sicer lahko izpeljemo iz predložnih zvez, rodilniške *sb̆ měra, orodniške *sъ měròmb oz. mestniške *nâ měrě, zadnjega, namirom pa ne, saj se na ne veže $\mathrm{z}$ orodnikom, zato je tudi navedeno izvajanje prvih štirih vprašljivo. Pred prikazom boljše možnosti si moramo najprej ogledati izvor in etimološko razlago samostalnikov *měrb in *mêr $\nleftarrow$.

4.2 Beseda *mêr b je $\mathrm{v}$ ustreznem pomenu potrjena le $\mathrm{v}$ nar. sloven. mệr, merî 'smer'. Izvorno je to nedvomno postverbal strelskega termina *mě́riti 'določati smer pri streljanju' < 'določati mero', ki je denominativ od *měra. Poltematski glagoli pa imajo atematskih $i$-jevskih postverbalov tudi tematske $a$-jevske ženskega in $o$-jevske moškega spola. Tematski postverbali iz nesestavljenih glagolov navadno sodijo v premično akcentsko paradigmo, postverbali iz sestavljenih pa v nepremično, prim. hrv.,

${ }^{8}$ Trubar, Ena dolga predguvor.

${ }^{9}$ Grimm, Deutsches Wörterbuch I, 819.

${ }^{10}$ Navajajo Hraste, Šimunović, Olesch, Čakavisch-deutsches Lexikon III, 546.

${ }^{11}$ Navajata Rožić, Rad JAZU CXVIII, 60, Jedvaj, Hrvatski dijalektološki zbornik I, 320.

${ }^{12} \mathrm{O}$ pojavu Ramovš, Historična gramatika slovenskega jezika II, 72. 
srb. stâv - pòstav < *stâvb - *postâv'b iz *(po-)stâviti, vîd - prévid <*vîdb *per-vídb iz *(per-)víděti. Tako sta npr. iz * primếriti tvorjena sloven. postverbala primêr, -éra in primẹra. Izvor prislovov zmẹraj in zmêrom je torej verjetneje kot $\mathrm{v}$ predložnih zvezah ${ }^{13}$ treba iskati $\mathrm{v}$ otrdelem rodilniku ${ }^{*}$ sъmérra oz. orodniku ${ }^{*}$ sъmě́romb postverbala $*_{s b m e \tilde{r} r}$, ohranjenega v češ. směr 'smer', ${ }^{14}$ dovršnega glagola $*_{S b}$ mĕriti 'nameriti, določiti smer'. $\mathrm{V}$ prid tej možnosti govori akcent $\mathrm{v}$ čak. smìron, ki kaže na stari akut, tega pa pri izvajanju iz *mêrb ne bi pričakovali. ${ }^{15}$ Mutatis mutandis velja enako za namiru/namiri in namirom, ki sta iz mestnika oz. orodnika postverbala iz dovršnika *namĕ́riti > csl. naměriti, sloven. namériti 'usmeriti orožje proti cilju'.

5 Opisana interpretacija dejstev in indicev izkaže sorodstvene vezi med obravnavanimi prislovi tako, da je celotna slika $\mathrm{z}$ vsemi njenimi posameznimi deli vred skladna $\mathrm{z}$ ustreznimi jezikoslovnimi in zunajjezikovnimi spoznanji. To pomeni, da je metodološko korektna, iz česar smemo presoditi, da predstavlja znanstveno resnico, tj. ugotovitev, ki velja, dokler se ne najde verjetnejša razlaga.

Prispelo oktobra 2002, sprejeto januarja 2003

Received October 2002, accepted January 2003

\section{Slovensko vedno, zmeraj in sorodno}

Površen pogled na sloven. prislov vmèr 'vedno, zmeraj' lahko privede do zgrešene možnosti razlage, po kateri naj bi bila beseda tvorjena po zgledu istopomenske nem. immer, razumljene kot sestavljenke $\mathrm{z}$ in ' $\mathrm{v}$ ', kar naj bi $\mathrm{v}$ sloven. prevedli $\mathrm{z} v$, in nekega ne več prevedljivega elementa mer, ki naj bi v sloven. vmër ostal nespremenjen. S tem se odpre možnost poiskati nem. jedro še istopomomenskim prislovom zmẹraj, zmêrom in vẹnomer.

Tako razmišljanje je zgrešeno, saj si zaradi enega osamljenega indica zakriva oči pred popolnoma drugačno celotno sliko. Nemški prislov immer seveda ni sestavljenka s prvim členom iz nem. in, temveč je sklop iz srvnem. iemmer < stvnem. iommer , kar vsebuje srvnem. io < stvnem. eo 'vedno', to pa onemogoča paretimološko navezavo na nem. in ' $\mathrm{v}$ ' in $\mathrm{s}$ tem tako domnevno razumevanje sloven. tvorca prislova vmër. Ključ za rešitev tega in sorodnih sloven. prislovov je Miklošičeva razlaga prislova venomệr iz sklopa *v'b edbnè mếrb, pri čemer *mêrb, ki se ohranja v nar. sloven. mẹr, rod. merî, pomeni 'smer'. K semantičnemu razvoju prim. nem. in einem fort 'neprestano' s fort 'naprej', pa tudi sloven. kar naprej 'neprenehoma, stalno, ve-

${ }^{13}$ Tako Snoj, Slovenski etimološki slovar, 750.

${ }^{14}$ Iz tega je prevzeto sloven. smẹr in hrv. smjêr. Indikacije na premično akcentsko paradigmo lahko v češ. pripišemo vplivu simpleksa, prim. tako hrv., srb. ïzvīd po vîdd.

${ }^{15}$ Sloven. novi cirkumfleks v zmẹraj in zmệrom je problematičen. Ker v prislovih na $-a j$ praviloma ne zasledimo metatonije, prim. zjútraj $<* j b z$ jütra $+j b$, je novi cirkumfleks tu verjetno analogen po zmệrom, kjer je razložljiv kot $\mathrm{v}$ prislovih tipa čâsoma, ki prav tako izvirajo iz orodniških oblik na -omb, prim. hrv., srb. čâsom. Zakaj se je v večini teh prislovov vzpostavil novi cirkumfleks, je težko vprašanje. Ker so s pripono -om(a) sekundarno tvorjeni tudi prislovi iz tematskih ženskih osnov, npr. sîloma $=$ hrv., srb. sìlom, ni izključeno, da je novi cirkumfleks v čâsoma nastal v analognem razmerju *síl- : čấs- $=*_{\text {sílojo }}>$ sîlo $\rightarrow$ sîloma $: \mathrm{x} ; \mathrm{x}=$ čâsoma . 
dno'. Zveza *v'b edbnò mếrb se je eliptično skrajšala na dva načina: z odpadom prilastka dobimo vmèr, $\mathrm{z}$ odpadom jedra pa *vednọ. Nadaljnja obrusitev je znana $\mathrm{v}$ sloven. reduplicirani zvezi vèn in vèn 'kar naprej, vedno'. S predlogom *vbz je tvorjen prislov sloven. zmệr 'vedno', hrv. kajk. vúzmer <*vъz (edbnò) mêrb.

Iz akcentske analize prislova védno, še bolj obvezujoče pa iz istopomenskih prislovov namiru/namiri, namirom, zmẹraj, zmẹrom, hrv. čak. smïron in kajk. zmirom je treba sklepati na tematski samostalnik *(-)měr s moškega spola. Medtem ko je $i$-jevski samostalnik *mêrb 'smer' postverbal nesestavljenega strelskega termina *mếri$t i$ 'usmerjati orožje proti cilju' < 'delati mero', so navedeni prislovi najlažje razložljivi kot otrdeli mestnik, rodilnik oz. orodnik postverbalov sestavljenih dovršnikov *namếriti oz. *sъmếriti 'nameriti, določiti smer'. Tematski postverbal iz *sъmě́riti se kot samostalnik ohranja v češ. směr 'smer', od koder je v 19. stol. prevzeto sloven. smẹr in hrv. smjêr.

\section{Slovene vedno, zmeraj and Related Forms}

A first glance at the Slov. adverb vmèr 'always' can lead to an incorrect interpretation according to which the word is formed on the model of the synonymous German immer, understood as a compound of in 'in', calqued as Slov. $v$, and a now untranslatable element mer, which would have remained unaltered in Slovene vmër. This then opens the possibility of seeking a German starting point for the synonymous adverbs zmệraj, zmẹrom and vẹnomer.

This view is incorrect, as the circumstantial evidence obscures the full picture, which is completely different. The Germ. adverb immer is clearly not a compound containing the first element from Germ. in, but is rather a concatenation from MHG iemmer < OHG iommere, containing MHG io < OHG eo 'always', which precludes a paraetymological connection with Germ. in 'in' as well as with the presumed interpretation of the Slovene formant of the adverb vmèr. The key to the solution of this and related Slovene adverbs is found in Miklošičs explanation of the adverb venomẹr from the concatenation of $*_{v b} e d b n \dot{Q} m \tilde{e} r b$, in which $* m e \tilde{r} r$, is preserved in Slov. dial. mẹr, gen. merî, meaning 'direction'. As to the semantic devlopment, cf. Germ. in einem fort 'constantly' with fort 'forward, ahead', as well as Slov. kar naprej 'continually, constantly, always'. The concatenation *vъ edbnè mêr became elliptically shortened in two ways: with the loss of the attribute the result is vmèr, the loss of the head results in *vednọ. Further shortening is found in the Slov. reduplicated syntagm vèn in vën 'constantly, always'. The addition of the prefix *vbz forms the Slov. adverb zmẹr 'always', Cr. Kajk. vúzmer <*vъz (edbnò) mêrb.

An accentological analysis of the adverb védno, as well as the more compelling synonymous adverbs namiru/namiri, namirom, zmêraj, zmêrom, Cr. Čak. smïron and Kajk. zmirom points to a thematic masculine noun in *(-)měr $b$. While the $i$-stem noun *mêrb 'direction' is a postverbal of the non-compound marksmanship term *mériti 'to direct a weapon at a target' < 'to take aim', the adverbs adduced can be most easily explained as fossilized locative, genitive, or instrumental postverbals of the compound perfectives *namériti or *s'bmériti 'to aim, to determine a direction'. The thematic postverbal from *şmĕriti is preserved as a noun in $\mathrm{Cz}$. směr 'direction', from which Slov. smẹr and Cr. smjêr were borrowed in the nineteenth century. 